М.М. Логвиненко ${ }^{1}$, Д.С. Печура ${ }^{1}$, С.М. Сторожук ${ }^{1}$, О.В. Вабіщевич ${ }^{1}$

${ }^{1}$ Державний науково-дослідний інститут авіаиії, Київ

\title{
МЕТОДИКА ОЦІНЮВАННЯ ЕФЕКТИВНОСТІ ЗАСОБІВ ОПТИКО - ЕЛЕКТРОННОГО ПОДАВЛЕННЯ В УМОВАХ ПРОТИДІЇ ЗЕНІТНИМ КЕРОВАНИМ РАКЕТАМ
}

У статті запропоновано методичні підходи до оцінювання ступені захищеності літального апарата у процесі подолання зони протиповітряної оборони, яка контролюється розрахунком переносного зенітного ракетного комплексу. Для кількісної оичнки процесу придушення інфрачервоних головок самонаведення зенітних керованих ракет авіаційними засобами оптико-електронної протидії авторами запропоновано використовувати один із показників бойової ефективності, а саме зміну площі зони можливих атак. Використання зазначеного показника ефективності захисту літального апарату дозволяє об'єктивно оцінити вплив окремих факторів на прочес наведення ракети та визначити иляхи збільшення ефективності захисту. Запропонована методика оцінки ефективності захисту літального апарату від зенітних ракет з інфрачервоними головками самонаведення дозволяє виконати це як якісно, так $і$ кількісно.

Ключові слова: інфрачервона головка самонаведення, оптико-електронне подавлення, показники ефективності.

\section{Вступ}

Аналіз досвіду ведення бойових дій останніх десятиліть свідчить, що при нанесені ударів по наземних цілях літальні апарати (ЛА) постійно діють в умовах протидії засобів протиповітряної оборони противника, а саме під вогнем переносних зенітних ракетних комплексів (ПЗРК).

Бойові задачі протиповітряної оборони наземних об'єктів і військ зенітні ракетні підрозділи вирішують веденням вогню по повітряним цілям 3 метою їх знищення (ураження). Організоване ведення вогню, що направлене на знищення засобів повітряного нападу або розвідки, $€$ основним замислом бою, який ведеться 3 широким застосуванням маневру вогнем, силами і засобами. Бій зенітних ракетних підрозділів відбувається швидкоплинно і ведеться в умовах застосування повітряним противником усього комплексу засобів протидії. Стрільба зенітного підрозділу складається 3 підготовки до стрільби, проведення пусків або ведення вогню і оцінювання результатів стрільби.

Підготовка до стрільби - процес бойової роботи підрозділу до пуску ракет, направлений на забезпечення максимальної ефективності ведення вогню по повітряній цілі. Ведення вогню - процес бойової роботи, пов'язаний з наведенням ракет від моменту пуску до підриву ракети.

Метою кожного окремого випадку стрільби є ураження цілі. Під ураженням цілі розуміють іiі знищення або нанесення ій такого пошкодження, при якому вона не може виконувати поставлену бойову задачу. Міру відповідності результату стрільби по повітряній цілі до поставленої задачі називають ефективністю стрільби, яка характеризується показниками ефективності.

У роботах $[1,2]$ наведено, що вибір показників ефективності стрільби визначається задачею стрільби і тактико-технічними характеристиками повітряної цілі. При оцінюванні зазначених показників ефективності приймається припущення, що підготовку до стрільби вже проведено і пуск зенітних керованих ракет по цілі відбувся. Ураження повітряної цілі в такому випадку залежить від великої кількості факторів, що безпосередньо впливають на процес стрільби.

Проведений аналіз наведених методів оцінювання ефективності засобів оптикоелектронного подавлення в умовах протидії зенітним керованим ракетам 3 інфрачервоними головками самонаведення дозволяє стверджувати, що вони не враховують величину площі зони можливих атак як кількісного та якісного показника ефективності стрільби $[1,2]$.

\section{Виклад основного матеріалу}

Ураження цілі зенітною керованою ракетою можливо представити у вигляді складної випадкової події, що складається 3 двох інших послідовних випадкових подій.

Перша випадкова подія полягає у тому, що підрив бойової частини (БЧ) ракети відбувся у точці простору 3 координатами $x, y, z$ відносно цілі. Імовірність цієї події визначимо як похибку 
$f(x, y, z)$, що супроводжує стрільбу. Друга випадкова подія полягає в тому, що елементи ураження БЧ, яка вибухнула у точці з координатами $x, y, z$, уразять ціль. Імовірність цієї події визначимо координатним законом ураження цілі $G(x, y, z)$.

Ймовірність підриву БЧ ракети у точно визначеній точці простору практично дорівнює нулю. Тому ймовірність першої події визначимо як імовірність підриву БЧ в елементарному об'ємі $d x, d y, d z$ навколо точки $x, y, z$, а саме величиною $f(x, y, z) d x, d y, d z$.

Ймовірність складної події $d P$ полягає у тому, що підрив БЧ ракети відбудеться у точці $P 3$ координатами $x, y, z$ (в елементарному об’ємі $d x, d y, d z$ ) та елементи ураження попадуть в ціль, визначаються за теоремою множення ймовірностей:

$$
d P=f(x, y, z) d x d y d z \cdot G(x, y, z),
$$

Відповідно до закону похибок, що супроводжують стрільбу, підрив БЧ може виникнути не лише у точці $x, y, z$, а й у будь-якій точці простору біля цілі. Отже, для визначення ймовірності ураження цілі при пуску однієї ракети використаємо формулу повної ймовірності:

$$
\Pi=\sum_{i=1}^{n} Q_{i} P_{i},
$$

де $\Pi$-повна ймовірність події без урахування гіпотези, за якою вона відбулася; $Q_{i}$ - ймовірність гіпотези; $P_{i}$ - ймовірність події згідно гіпотези; $n-$ загальна кількість гіпотез.

Гіпотезами стрільби у даному випадку $є$ припущення про координати $x, y, z$ точки підриву БЧ, а подія, згідно гіпотези - ураження цілі за умови підриву ракети у точці з координатами $x, y, z$.

$\mathrm{y}$ зв'язку з тим, що гіпотези є випадковими значеннями трьох безперервних випадкових величин, то сума парних добутків у формулі (2) замінимо інтегралом:

$$
P_{1}=\int_{-\infty}^{+\infty} \int_{-\infty}^{+\infty} \int_{-\infty}^{+\infty} f(x, y, z) G(x, y, z) d x d y d z
$$

де $P_{1}$ - ймовірність ураження цілі однією ракетою.

Функція $f(x, y, z)$ відмінна від нуля лише у невеликому обсязі поблизу цілі, а для більшості зенітних керованих ракет, що входять до складу ПЗРК (у зв'язку 3 відсутністю неконтактного підривача), обмежено контуром повітряної цілі. У цьому обсязі і виконують інтегрування. Розсіювання точок підриву БЧ відносно цілі виникає внаслідок помилок наведення ракети на ціль і розкидання точок спрацювання неконтактного підривача

$$
f(x, y, z)=f(y, z) w(x, y, z) .
$$

$\mathrm{y}$ свою чергу, закон спрацювання неконтактного підривача має вигляд

$$
w(x, y, z)=f_{1}(x / y, z) f_{2}(y, z),
$$

де $f_{1}(x / y, z)$ - щільність розподілу координат спрацювання підривача 3 обумовленою помилкою наведення $y, z ; f_{2}(y, z)$ - імовірність спрацювання підривача по цілі залежно від помилок наведення.

Якщо ввести поняття умовного координатного закону ураження цілі, отримаємо:

$$
G_{0}(y, z)=\int_{-x_{\max }}^{+x_{\max }} G(x, y, z) f_{1}(x / y, z) d x .
$$

3 урахуванням (4) та (5) ймовірність ураження повітряної цілі однією ракетою визначимо залежністю:

$$
P_{1}=\int_{-\infty}^{+\infty} \int_{-\infty}^{+\infty} f(y, z) f_{2}(y, z) G_{0}(y, z) d y d z
$$

Аналіз виразу (7) показує, що для визначення ймовірності ураження повітряної цілі однієї ракетою необхідно знати:

закон помилок наведення ракети на ціль $f(y, z)$;

залежність ймовірності спрацювання неконтактного підривача від помилок наведення $f_{2}(y, z)$;

умовний координатний закон ураження цілі $G_{0}(y, z)$.

Для зниження ефективності бойових дій ЗРК пілотовані літальні апарати можуть виконувати протиракетний маневр та застосовувати засоби радіо-електронної боротьби.

Початок виконання i вид протиракетного маневру планується заздалегідь або залежно від особливостей зенітних комплексів противника, або згідно з інформацією, що отримав льотчик під час виконання бойового завдання.

Протиракетний маневр цілі залежно від часу і місця виконання можливо розділити на маневр проти управління і маневр проти стрільби.

Маневр проти управління здійснюється до пуску ракети 3 метою суттєвого ускладнення управління і скорочення кількості стрільб зенітних ракетних комплексів.

Маневр проти стрільби виконується після пуску ракети з метою уникнення зустрічі 3 нею або зниження ефективності стрільби. Зустріч ракети 3 ціллю у зоні ураження може не відбутися, якщо час, необхідний літальному апарату на виконання маневру за зоною ураження ПЗРК, менший, ніж польотний час ракети до точки зустрічі із ціллю.

Застосування засобів оптико-електронної протидії літальними апаратами може призвести до зростання помилок наведення ракети, зниження 
ефективності дії БЧ, порушення нормального функціонування елементів ракетного комплексу та до зриву наведення ракети. Ймовірність $P_{\text {зр }}$ порушення нормального функціонування ракети, що знаходиться під впливом засобів оптикоелектронного подавлення, визначається

$$
P_{3 p}=P_{o p 2} P_{n} P_{\kappa},
$$

де $P_{\text {орг }}$ - ймовірність того, що буде організовано завади; $P_{n}$-ймовірність проходження завади в блок системи управління ракети; $P_{\kappa}-$ ймовірність того, що потужність сигналу завади достатня для порушення нормального функціонування ракетного каналу управління.

Ймовірність $P_{\phi}$ нормального функціонування ПЗРК в умовах оптико-електронної протидії визначається за формулою

$$
P_{\phi}=1-\prod_{i=1}^{m} P_{3 p_{i}},
$$

де $m$-кількість засобів подавлення, що застосовано одночасно; $P_{3 p_{i}}$ ймовірність порушення нормального функціонування системи наведення ракети за рахунок впливу одного із засобів оптикоелектронного подавлення.

Застосування засобів оптико-електронного подавлення i виконання протиракетного маневру може привести до зниження кількості пусків та зниження ефективності ураження [1].

Другим важливим, показником ефективності $\epsilon$ зона ураження. Зоною ураження є частина простору навколо повітряної цілі, у межах якої забезпечується iii ураження зенітною керованою ракетою із заданою ймовірністю. Розміри зони ураження визначаються шляхом співвідношення балістичних характеристик ракети і цілі. Межі зони ураження зображають у полярній системі координат.

Для гарантованої зустрічі ракети з ціллю у зоні ураження необхідно завчасно виконувати пуск ракети з урахуванням польотного часу до точки зустрічі та швидкості цілі.

Частина простору, в якій відбудеться зустріч ракети з ціллю та іiі ураження, є зоною можливих пусків. Розміри зони можливих пусків та ії межі, за умови відомих меж зони ураження і часу польоту ракети, залежать від швидкості і траєкторії цілі.

Положення меж зон ураження загалом залежать від значної кількості факторів, які пов'язані $з$ характеристиками зенітного комплексу та повітряної цілі й умовами стрільби.

Для літального апарату, що застосовує засоби оптико-електронного подавлення інфрачервоних головок самонаведення (ІГС) зенітних керованих ракет, найбільш інформативним показником оцінювання ефективності його захисту $є$ зона можливих атак. Зона можливих атак - це геометричне місце точок на земній поверхні, при пусках 3 яких ракета уражає ціль із заданою ймовірністю. Загалом, на розміри і конфігурацію зони можливих атак впливають:

льотно-балістичні та маневрові характеристики ракети;

параметри контуру управління та метод наведення ракети;

характеристики бойового спорядження;

можливості ІГС супроводжувати ціль;

льотні характеристики, індикатриса інфрачервоного випромінювання та вразливість літального апарату;

умови стрільби (наявність засобів оптикоелектронного подавлення та маневрування цілі) тощо.

Зона можливих атак характеризується положеннями дальньої та ближньої меж i зображується у полярній системі координат, в центрі якої розміщено проєкцію положення літального апарату на земну поверхню. Положення дальньої межі зони можливих атак визначається такими координатами місця пуску ракети, 3 яких ефективність стрільби буде не нижче заданої. Ймовірність ураження цілі однією ракетою функціонально залежить від похибок наведення ракети та характеристик умовного закону ураження цілі. Для визначення положення дальньої межі зони можливих атак необхідно провести аналіз умов нормального процесу наведення ракети на ціль.

Параметри руху цілі, разом 3 методом наведення ракети при заданих початкових умовах пуску i швидкості ракети $V_{p}(t)$, визначають потрібну траєкторію польоту ракети. Кривизну потрібної траєкторії характеризують величиною нормального перевантаження ракети для відтворення цієї траєкторії. Потрібні перевантаження, які обумовлені методом наведення i характером руху цілі, прийнято називати кінематичними і позначають $n_{k}$.

Реальна здатність до маневру зенітної ракети характеризується наявним перевантаження $n_{H}$, а саме, нормальним перевантаженням ракети, яке можливо отримати за умови максимальної величини команди управління.

Нормальне наведення на ціль можливо тільки якщо наявне перевантаження ракети більше за потрібне кінематичне на величину

$$
\Delta n=n_{B}+n_{w}+n_{\phi},
$$

де $n_{b}$ - вагова складова потрібного перевантаження; $n_{w}$-перевантаження, що використовується на 
компенсацію подовжнього прискорення ракети; $n_{\phi}$-потрібне перевантаження для відпрацювання випадкової складової команди управління.

Таким чином, необхідною умовою нормального наведення ракети на ціль $€$

$$
n_{H} \geq n_{n}
$$

де $n_{n}=n_{\kappa}+n_{w}+n_{\phi}$.

Невиконання умови (10) призводить до збільшення промаху ракети. У загальному випадку функцію промаху можливо представити у вигляді

$$
\begin{aligned}
& \Pi=\Pi\left\{A_{u}\left(H, V_{u}, n_{u_{x}}, n_{u_{y}} n_{u_{z}}\right)\right\} ; \\
& A_{p}\left[H, V_{p},\left(T_{\partial}, c\right) n_{\partial}\right] ; A_{c y}\left(w_{D}, w_{D \partial}, \Delta w_{D}\right)
\end{aligned}
$$

де $A_{u}\left(H, V_{u}, n_{u_{x}}, n_{u_{y}} n_{u_{z}}\right)$ - параметр, що визначає траєкторію руху цілі та залежить від висоти цілі $H$, швидкості цілі $V_{u}$ і перевантаження цілі у трьох взаємоперпендикулярних

площинах; $A_{p}\left[H, V_{p}\left(T_{\partial}, c\right) n_{\partial}\right]-$ параметр, що визначає енергетичні та траєкторні характеристики ракети i залежить від тяги ракетного двигуна, балістичних характеристик ракети $c$ i допустимого перевантаження ракети $n_{\partial} ; A_{c y}\left(w_{D}, w_{D \partial}, \Delta w_{D}\right)-$ функція, що визначає точність роботи системи управління ракети у залежності від кутової швидкості лінії дальності $w_{D}$, ï допустимого значення $w_{D \partial}$, точності роботи ІГС, що призводить до похибок під час вимірювання кутової швидкості лінії дальності $\Delta w_{D}$

Визначення дальньої межі зони можливих атак залежить від розв'язання системи кінематичних рівнянь, що описують взаємний рух цілі та ракети за умови поступових змін таких параметрів ракети: місце пуску, швидкість і ії̈ перевантаження [2; 3].

Задача 3 визначення дальньої межі зони можливих атак значно спрощується, якщо прийняти гіпотезу, що літальний апарат не маневрує, а летить прямолінійно на одній висоті 3 постійною швидкістю. Такі умови польоту приймають для попереднього оцінювання зони можливих атак, що дозволяє визначати вплив маневру ЛА та застосування ним засобів оптико-електронного подавлення на траєкторію руху ракети і зміну конфігурації зони можливих атак.

Умова (10) є основним фактором, що впливає на положення дальньої межі зони можливих атак. Але в процесі оцінювання бойових можливостей зенітного ракетного комплексу необхідно враховувати й інші фактори, що безпосередньо пов'язані $з$ характеристиками системи управління ПЗРК. Так, наприклад, положення дальньої межі зони можливих атак визначається максимальною дальністю дії ІГС зенітної ракети.

Для визначення максимальної дальності дії ІГС розглянемо декілька можливих мішенних ситуацій:

ціль знаходиться на випромінюючому фоні; ціль знаходиться на не випромінюючому фоні; ціль знаходиться на однорідному небесному фоні; ціль знаходиться на неоднорідному небесному фоні. У першому випадку величина інфрачервоного потоку випромінювання одинокої цілі $\Phi_{u}$, що впливає на приймач випромінювання ІГС, згідно 3 [3] визначається за формулою

$$
\Phi_{u}=\tau_{0} S_{0} k I_{u} L^{-2},
$$

де $\tau_{0}-$ коефіцієнт пропускання оптичної системи; $S_{0}$ - робоча площа оптичної системи; $I_{u}$ - сила інфрачервоного випромінювання цілі під визначеним ракурсом спостереження; $L$ - відстань між ціллю та IГC; $k-$ коефіцієнт використання приймача випромінювання, що визначається за формулою [4]

$$
k=\frac{\int_{\lambda_{1}}^{\lambda_{2}} r_{\text {вid }}(\lambda) S_{\lambda}(\lambda) \tau_{a} d \lambda}{\int_{\lambda_{1}}^{\lambda_{2}} r_{\text {вid }}(\lambda) d \lambda},
$$

де $\lambda_{1}, \lambda_{2}-$ верхня та нижня межі спектрального діапазону роботи приймача випромінювання, відповідно; $\quad S_{\lambda}(\lambda)$ - спектральна чутливість приймача випромінювання; $\tau_{a}=\tau_{H_{2} O} \cdot \tau_{c o_{2}} \cdot \tau_{d}-$ коефіцієнт пропускання атмосфери (залежить від коефіцієнтів поглинання випромінювання водяною парою, вуглекислим газом та розсіювання випромінювання молекулами повітря відповідно); $r_{\text {вid }}(\lambda)$ - відносна щільність потоку випромінювання.

Коефіцієнт $k$ враховує спектральний склад інфрачервоного потоку випромінювання цілі, спектральні характеристики приймача випромінювання та пропускання атмосфери.

3 формули (12) отримуємо вираз для визначення максимальної дальності дії ІГC, яка виконує свої функції стосовно виявлення та супроводження цілі за умови, що

$$
\Phi_{u}=m \Phi_{n o p},
$$

де $m$ - коефіцієнт стійкої роботи ІГС; $\Phi_{n o p}{ }^{-}$ порогова чутливість ІГС.

У цьому випадку

$$
L_{\max }=\left(\frac{\tau_{0} S_{0} k I_{u}}{m \Phi_{n o p}}\right)^{1 / 2},
$$


Найбільші складності виникають у зв’язку 3 розрахунками спектрального коефіцієнта пропускання атмосфери $\bar{c}_{a}$.

Відомо [4...8], що інфрачервоний потік випромінювання при проходженні через атмосферу поглинається водяною парою, вуглекислим газом та озоном, а також розсіюється молекулами повітря, розмір яких значно менший за довжину хвилі випромінювання. Коефіцієнти $\tau_{\mathrm{H}_{2} \mathrm{O}}, \tau_{\mathrm{CO}_{2}}, \tau_{d}$ неявно залежать від відстані між ціллю та ІГС, висоти польоту цілі, параметрів стану атмосфери (абсолютної температури і відносної вологості повітря, метрологічної дальності видимості тощо).

Для визначення величини потоку інфрачервоного випромінювання приймачем випромінювання ІГС від фону і цілі одночасно необхідно врахувати, що частина площі випромінювання фону екранується ціллю. У цьому випадку величина потоку випромінювання $\Delta \Phi$ згідно з $[9,10]$ визначається як

$$
\Delta \Phi=\Phi_{\phi}^{*}+\Phi_{u}-\Phi_{\phi},
$$

де $\Phi_{\phi}^{*}-$ потік інфрачервоного випромінювання, який враховує, що частина площі фону (що дорівнює площі цілі) екранується ціллю; $\Phi_{\phi}-$ потік інфрачервоного випромінювання від однорідного (рівномірного) небесного фону, що визначається як

$$
\Phi_{\phi}=\tau_{0} S_{0} k_{\phi} I_{\phi} L^{-2},
$$

де $I_{\phi}$ - сила інфрачервоного випромінювання небесного фону; $k_{\phi}$-коефіцієнт використання приймача випромінювання.

3 урахуванням (14...16) отримаємо

$$
L_{\max }=\left[\frac{\tau_{0} S_{0}}{m \Phi_{\text {nop }}}\left(k I_{u}-k_{\phi} I_{u}\right)\right]^{-1 / 2} .
$$

За умови наявності у полі зору оптичної системи ІГС неоднорідного фону, флуктуаційний сигнал на виході приймача буде містити складову, що обумовлена модуляцією фону, значно перевищує власні шуми приймача випромінювання і $\epsilon$ випадковою функцією часу. У даному випадку вплив фонового випромінювання на ІГС аналогічний впливу на неї хибної теплової цілі. Тоді вихідний сигнал залежить від виду модуляції потоку випромінювання, що застосовується в ІГС.
Максимальна дальність дії ІГС пропорційна індикатрисі сили випромінювання цілі та в реальних умовах залежить від типу цілі і може змінюватися в широких межах. Якщо максимальна дальність дії IГС є меншою за потрібну (балістичну) дальність, то зменшиться не лише розрахункова зона ураження, а й зона можливих атак. Фактори, що визначають положення ближньої межі зони можливих атак, обумовлені конструктивними особливостями зенітної ракети, що впливають на її траєкторію і час зведення системи підриву бойової частини.

Траєкторія зенітної ракети розділяється на три ділянки: ділянка неконтрольованого польоту ракети (початкова ділянка), ділянка виводу ракети на потрібну траєкторію (ділянка відпрацювання початкового розузгодження), ділянка наведення.

Протяжність у часі перших двох ділянок визначає віддалення ближньої межі зони можливих атак. Час польоту ракети на початковій ділянці польоту, загалом, залежить від часу роботи схеми обнуління, яка блокує сигнали управління ракетою протягом роботи стартового двигуна і виході на режим маршового.

У системах самонаведення 3 ІГС початкова похибка визначається положенням вектору швидкості ракети відносно миттєвої точки зустрічі. Для забезпечення зустрічі ракети з ціллю необхідно так скерувати вектор швидкості ракети, щоб промах ракети не перевищував максимально допустиме значення.

Величина максимального кута місця, на яку може бути повернута ракета ПЗРК, обумовлена вимогами до безпеки стрілка i, як правило, не перевищує $60^{\circ}$. Залежність ближньої межі зони можливих атак $l$ від висоти польоту ЛА має вид:

$$
l=\frac{H}{\operatorname{tg} \varphi_{\max }},
$$

де $H$ - висота польоту цілі; $\varphi_{\max }-$ максимальний кут місця.

Висока ефективність ПЗРК вважається основною бойовою властивістю цього виду зброї. Тому, за умови виявлення пуску ракети, екіпаж обстріляного ЛА буде застосовувати всі наявні засоби для уникнення ураження: виконання маневру на максимально допустимому перевантаженні із зміною напрямку та збільшення швидкості польоту 3 метою виведення ЛА із зони ураження. Результативність такого маневру буде успішною, 
якщо необхідний ЛА час для виходу із зони ураження менший, ніж польотний час ракети до точки зустрічі. Відлік часу починається 3 моменту початку маневрування. Найбільшим запасом часу для маневрування або застосування засобів протидії екіпаж буде мати у випадку отримання апаратурного оповіщення про пуск ракети із зони можливих атак.

Застосування засобів оптико-електронної протидії, під час виконання бойових завдань, $\epsilon$ одним з необхідних та обов'язкових заходів.

Розробка засобів протидії інфрачервоним головкам самонаведення керованих ракет, як правило, виконується паралельно за трьома основними напрямками: розробка засобів зменшення інфрачервоного випромінювання власного ЛА та штучного погіршення прозорості атмосфери; створення пристроїв автоматичної фіксації моменту пуску ракети та супроводження іiі на траєкторії; розробка організованих завад у інфрачервоному діапазоні шляхом створення штучних джерел випромінювання $[12,13]$.

Класифікація способів та засобів оптикоелектронної протидії зенітним ракетам 3 ІГС наведена в [11]. Використання у якості показника ефективності захисту ЛА величини зміни площі зони можливих атак дозволяє об'єктивно оцінити вплив окремих факторів на процес наведення ракети та визначити шляхи збільшення ефективності захисту.

Для перевірки адекватності наведеної методики було розраховано сили інфрачервоного випромінювання літака Су-25 у 3-х можливих варіантах комплектації: у I варіанті силова установка літака складалася 3 двох турбореактивних двигунів Р-95Ш, у II - 3 двох двигунів Р-95ШУ, а у III - на вихідних соплах двигунів Р-95ШУ було розміщено екранно-вихлопний пристрій (ЕВП). Суттєвою відмінністю двигуна Р-95Ш від модернізованого двигуна Р-95ШУ $\epsilon$ те, що в останньому проведено конструктивні зміни вихідного сопла - впроваджено сопло 3 охолоджуваним центральним тілом. Аналогічне за конструкцією центральне тіло розміщено й у III варіанті силової установки, але додано екрануючі поверхні. В усіх 3-х випадках температура газу $T_{u}$

складає $1043^{\circ} \mathrm{K}$. Розрахунок сили випромінювання проведено для спектрального діапазону $\Delta \lambda=3,5 \ldots .5$ мкм під різними кутами спостереження та побудовано індикатриси сили випромінювання у трьох варіантах комплектації. Індикатриси випромінювання літака Су-25 у трьох варіантах комплектації відповідно у горизонтальній площині зображено на рисунку 1.

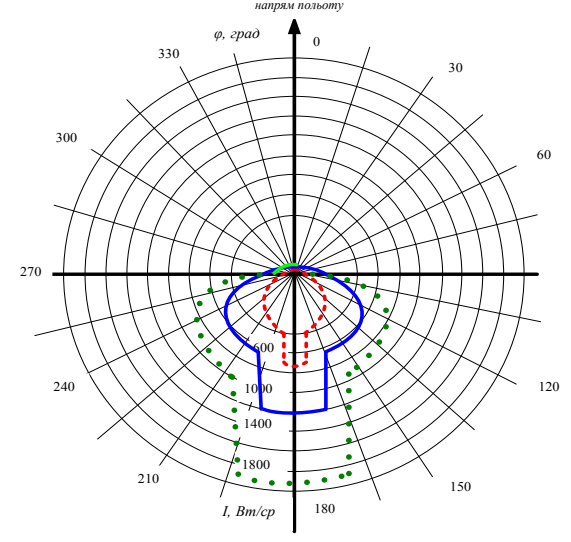

Рис.1. Індикатриси випромінювання літака типу Су-25

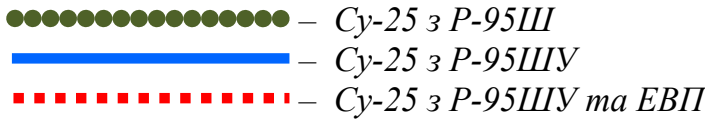

Джерело: Розроблено авторами.

Пропускання інфрачервоного випромінювання суттєво залежить від стану атмосфери $[11,12]$, і тому при розрахунках дальньої межі зони можливих атак прийнято параметри нормальної артилерійської атмосфери [9]: температура $T_{\text {пов }}=288,9$ К, тиск $P=1,00033 \mathrm{H} / \mathrm{m}^{2}$, вологість $f=80 \%$, метрологічна дальність видимості $d_{1}=20000$ м, висота польоту ЛА становить 100 м. Було розглянуто два варіанта швидкості польоту літака: максимальна $V_{\max }=269$ м $/$ с і крейсерська $V_{k}=236 \mathrm{~m} / \mathrm{c}$.

У результаті математичного моделювання побудовано три варіанти зони можливих атак літака типу Су-25 зенітною ракетою 9М39 ПЗРК “Игла" відповідно до варіанту комплектації силової установки, що зображено на рисунку 2.

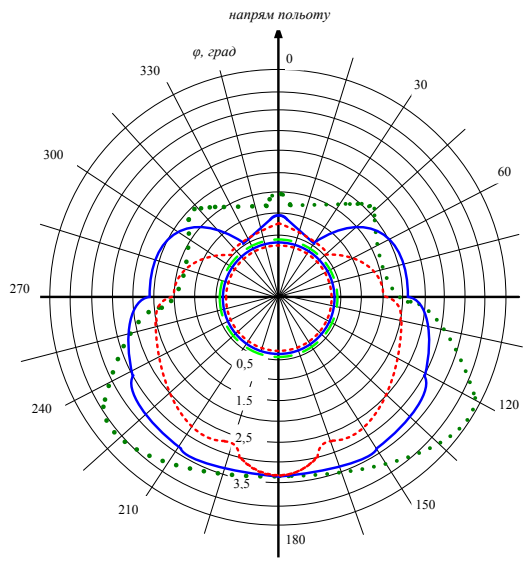

Рис.2. Зони можливих атак літака типу Су-25

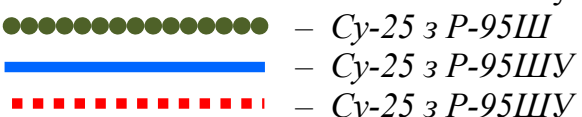

Джерело: розроблено авторами.

Аналіз результатів показує, що ближня межа зони можливих атак залишається незмінною в 
інтервалі висот польоту від 0 м до 865 м і становить 500 м. Крім того, значення ближньої межі зони можливих атак збільшується за умови збільшення висоти польоту літака, та на висотах більших 3100 м повністю поглинає зону можливих атак у передню напівсферу. На висотах 5200 м стрільба стає неможливою з усіх ракурсів.

Площа зони можливих атак літака типу Су-25 3 двигунами Р-95Ш ракетою 9М39 становить $S=15,82 \kappa^{2}$, $з$ двигунами Р-95ШУ - зменшиться на $8,6 \%$, а у третьому варіанті - зменшиться на 38,6 \%. Збільшення швидкості польоту літака типу Су-25 з крейсерської швидкості до максимальної зменшує площу зони можливих атак на 13,1 \%.
Отже, прийнявши гіпотезу, що пуск ракети може бути виконано 3 будь-якої точки зони можливих атак можна допустити, що пропорційно зменшенню площі зони можливих атак, викликаної впливом засобів оптико-електронної протидії, зменшується і ймовірність ураження.

\section{Висновки}

Таким чином, використання у якості показника ефективності захисту ЛА від зенітних ракет 3 інфрачервоними головками самонаведення величини площі зони можливих атак дозволяє оцінити ефективність захисту не тільки якісно, а й кількісно.

\section{Список літератури}

1. Неупокоев Ф.К. Стрельба зенитными ракетами. - М.: Воениздат, 1991. - 343 с.

2. Чуйко В.С. Внешняя баллистика авиационных ракет и снарядов. - М.: ВВИА им. проф. Н.Е. Жуковского, 1976. $235 \mathrm{c}$.

3. Защита самолетов от ракет с тепловыми головками самонаведения. - М.: Военное издательство, 1982. -384 с.

4. Криксунов Л.З.Справочник по основам инфракрасной техники. - М.: Сов. радио, 1978. - 400 с.

5. Лазарев Л.П., Инфракрасные и световые приборы самонаведения и наведения летательных аппаратов. - М.: Машиностроение, 1970. - 540c.

6. Хадсон Р. Инфракрасные системы. - М.: Мир, 1972. - 562 с.

7. Госсорг Ж. Инфракрасная термография. Основы, техника применения - М.: Мир, 1988. - 416 с.

8. Джемисон Дм. Э.Физика и техника инфракрасного излучения - М.: Советское радио, 1965. -624 с.

9. Криксунов Л.З. Инфракрасные координаторы цели.- К.: КВИАВУ ВВС, 1988. - 335 с.

10. Криксунов Л.З. Следящие системы с оптико-электронными координаторами.- К.: Техника, 1991. - 156 с.

11. Защита самолётов от ракет с тепловыми головками самонаведения. - М.: Воениздат, 1982. - 280 с.

12. Якушенков Ю.Г., Луканцев В.Н., Колосов М.П. Методы борьбы с помехами в оптико-электронных приборах.М.: Радио и связь, 1981. - 180 с.

13. Палий А.И. Радиоэлектронная борьба. - М.: Воениздат, 1982. - 250 с.

14. Логвиненко М.М., Вабишевич О.В., Ільіна О.В.Дослідження впливу хибних тепло випромінюючих цілей на інфрачервоні головки самонаведення керованих ракет // Зб.наук. праць.- К.: ДНДІА, 2016. - Вип.12(19). - С. 223-227.

15. Логвиненко М.М., Печура Д.С., Вабишевич О.В. Векторна модель автоматичного управління частотноімпільсною модуляцією // Зб.наук. праць. - К.: ДНДІА, 2017. - Вип.13(20). - С. 67-69.

\section{Відомості про авторів:}

\section{Логвиненко Микола Миколайович}

старший науковий співробітник

Державного науково-дослідного інституту авіації, Київ, Україна

https://orcid.org/0000-0002-1623-6654

\section{Печура Дмитро Сергійович}

кандидат технічних наук старший науковий співробітник начальник науково-дослідної лабораторії Державного науково-дослідного інституту авіації, Київ, Україна

https://orcid.org/0000-0002-5703-4039

\section{Information about the authors:}

\author{
Mykola Lohvynenko \\ Senior Researcher \\ of State Research Institute of Aviation, \\ Kyiv, Ukraine \\ https://orcid.org/0000-0002-1623-6654 \\ Dmytro Pechura \\ Candidate of Technical Sciences \\ Senior Researcher \\ Head of Research Laboratory \\ of State Research Institute of Aviation, \\ Kyiv, Ukraine \\ https://orcid.org/0000-0002-5703-4039
}




\section{Сторожук Сергій Миколайович}

старший науковий співробітник

Державного науково-дослідного інституту авіації, Київ, Україна

https://orcid.org/0000-0001-5271-0272

\section{Вабіщевич Олена Валентинівна}

науковий співробітник

Державного науково-дослідного інституту авіації, Київ, Україна

https://orcid.org/0000-0002-3286-4140

\section{Serhii Storozhuk}

Senior Researcher

of State Research Institute of Aviation, Kyiv, Ukraine

https://orcid.org/0000-0001-5271-0272

\section{Olena Vabishchevych}

Researcher Associate

of State Research Institute of Aviation, Kyiv, Ukraine

https://orcid.org/0000-0002-3286-4140

\title{
THE METHODS FOR EVALUATING THE EFFECTIVENESS OF OPTOELECTRONIC SUPPRESSION IN FACE OF ANTI-AIRCRAFT GUIDED MISSILES
}

\author{
M. Lohvynenko, D. Pechura, S. Storozhuk, O. Vabishchevych
}

The article proposes methodological approaches to assessing the degree of security of an aircraft in the process of overcoming the air defense zone controlled by the calculation of a portable anti-aircraft missile system. For a quantitative assessment of the process of suppressing infrared homing heads of anti-aircraft guided missiles by aviation means of opticalelectronic countermeasures, the authors proposed to use one of the indicators of combat effectiveness, taking into account their mutual influence. The most informative indicator of the effectiveness of the use of airborne optical-electronic countermeasures is the change in the area of the zone of possible attacks. The zone of possible attacks is the locus of points on the earth's surface when launched from which an anti-aircraft missile hits a target with a given probability, provided that the target does not maneuver and does not provide any countermeasures. The dimensions and configuration of the zone of possible attacks are determined by the tactical and technical characteristics of the anti-aircraft missile, flight characteristics, the survivability of the target and the availability of optical-electronic countermeasures in it, as well as the conditions of firing. The size of the zone of possible attacks is characterized by the position of the far and near boundaries and is depicted in the polar coordinate system at the beginning of which the projection of the position of the aircraft on the earth's surface is placed. capabilities of the missile's infrared homing head for target detection and tracking. The boundaries of the near zone are determined by the maneuverable characteristics of the missile and the time it reaches the homing area. The means of optoelectronic countermeasures are developing in three independent directions: development of means for reducing the intrinsic infrared radiation of the aircraft and artificially reducing the transparency of the atmosphere; development of false heat-emitting targets based on pyrotechnic compositions and devices for their use; development of optoelectronic suppression stations creating a stream of powerful simulated radiation. Each of the above countermeasures leads to a decrease in the instantaneous range of the infrared homing head of the attacking missile or to an error in the process of measuring the angular coordinates of the target, which in turn leads to an increase in missile miss and a decrease in the probability of the target position. The use of the value of the change in the area of the zone of possible attacks as indicators of the combat effectiveness of the protection of the aircraft makes it possible to objectively assess the influence of individual factors on the missile guidance process and determine the ways to increase the effectiveness of protection. The missile launch, equally likely, can be performed from any point in the zone of possible attacks. Under the influence of optical-electronic countermeasures, the area of the zone of possible attacks decreases and the probability of hitting the target decreases in proportion to it. The proposed method for assessing the effectiveness of the protection of a lethal vehicle from anti-aircraft missiles with infrared homing heads makes it possible to do this not only qualitatively, but also quantitatively.

Keywords: infrared seeker, optoelectronic suppression, efficiency indicators. 